\title{
The influence of rumors in the stock market: a case study with Petrobras
}

\section{A influência dos boatos no mercado de ações: um estudo de caso com a Petrobras}

\author{
Fábio Marques da CRUZ1 \\ Maria Yêda Falcão Soares de Filgueiras GOMES'
}

\begin{abstract}
This paper analyzes the influence of rumors on price fluctuations in the Stock Exchange of São Paulo between 2007 and 2011, through a case study with Petrobras, a company whose stock had the largest trading volume within the period. For this purpose we used the historical prices of cash market provided by the stock exchange. The communications in which Petrobras provides clarifications regarding unofficial information disclosed in the press were also collected from the stock exchange website. The analysis of these documents helped to create a diagram to represent the information about the rumors and categorize them by subject. This diagram was applied to a database to store the information collected from the company's communications. Then this information was retrieved to analyze the influence of rumors on price movements. The results confirm that the company's responses to rumors influence price fluctuations of its stock. At eagerness for information to dilute uncertainty, investors make decisions based on rumors betting on the credibility of the media that disclose them, even though knowing that the information is not always reliable.
\end{abstract}

Keywords: Informal flows. Intangible capital. Price fluctuation. Rumor. Stock market. Tacit knowledge.

\section{Resumo}

Este trabalho analisa a influência dos boatos nas oscilações de preços ocorridas na Bolsa de Valores de São Paulo entre os anos de 2007 a 2011, por meio de um estudo de caso com a Petrobras, empresa cujas ações tiveram o maior volume financeiro no período. Para tanto se utilizou o histórico de preços do mercado à vista fornecido pela bolsa. A partir do sítio da bolsa de valores, foram levantados os comunicados onde a Petrobras presta esclarecimentos em relação a informações não oficiais divulgadas pela imprensa. A análise desses documentos permitiu criar um diagrama para a representação das informações acerca dos boatos e categorizá-los por assunto. Esse diagrama foi aplicado a uma base de dados para armazenamento das informações coletadas nos comunicados. Em seguida, essas informações foram recuperadas para se analisar a influência dos boatos nos movimentos de preço. Os resultados comprovam que os boatos, assim como as respostas da empresa sobre eles, exercem influência nas oscilações de preço das suas ações. Os investidores, ávidos por informações para diluir a incerteza, tomam decisões com base em boatos apostando na credibilidade dos meios de comunicação que os divulgam, mesmo sabendo que nem sempre são informações confiáveis.

Palavras-chave: Fluxos informais. Capital imaterial. Oscilação de preço. Boato. Mercado de ações. Conhecimento tácito.

\footnotetext{
1 Universidade Federal da Bahia, Instituto de Ciência da Informação, Programa de Pós-Graduação em Ciência da Informação. Av. Reitor Miguel Calmon, s/n., Campus Universitário do Canela, 40110-100, Salvador, BA, Brasil. Correspondence to/Correspondência para: F.M. CRUZ.E-mail: <fabiomacz@gmail.com>. Received on 10/10/2012, resubmitted on 3/20/2013 and approved on 4/30/2013.
} 


\section{Introduction}

The aim of the paper was to analyze the influence of rumors on the price dynamics in the stock market through a case study with Petrobras - a company whose stock had the greatest financial volume from 2007 to 2011. This is a part of an ongoing Master's thesis in which the sample also includes other nine companies under analysis. Their stocks dealt with a lot of money within the period specified as did Petrobras.

When investors have a short amount of time to make a decision, it causes a feeling of urgency and an endless search for information that could reduce uncertainty. This situation makes them susceptible to rumors that go around the market and emerges as a way out of their lack of information in order to fulfill it. Information on the financial situation of companies not yet confirmed, but already broadcasted - the so called financial rumor - accelerates and becomes more trustable when it is released by the press, which sometimes publishes non-official information (Kapferer, 1993).

One of the tasks of the information transparency policy in publicly traded companies is to broadcast any information and material facts that could modify their securities. Therefore, when information is announced but not confirmed by the company, the stock exchange demands the organization to reveal the truth. However, the rumor can become stronger while the company remains silent. It gets worse when the news reaches those who are more eager to take risks. The longer a company takes to respond to the rumors, the higher is speculation and consequently, the greater is price fluctuation.

Considering these aspects on the stock market, this paper is organized in five sections - besides the introduction. In the other sections, other issues will be analyzed in more detail, such as the changes in the financial market after digital technologies, the studies on rumors, methods used, results and the final considerations.

\section{The information society}

Information is important for companies looking for more productivity and competitiveness. Besides, technological advances over the past decades have socially, economically, and culturally changed society resulting in the so-called information society.

Due to the advances in information and communication technologies, Le Coadic (2004) states two strong characteristics for the future: the quantitative explosion of information and the implosion of time of information communication. The Internet connected great financial centers and capital is flowing more naturally and faster in the global financial Web. This technological change has influenced the deregulation of the financial market.

When it comes to the stock market, one can notice the changes brought by the digital technologies, such as the electronic trading session and the home broker. The electronic stock quote replaced the trading floor operators making the control of the transactions and disclosure more agile and transparent. The home broker allows investors to send purchase and sell orders straight from their computers connected to the Internet.

Thus, digital technologies enabled easier flows of capital among countries, making their economy interdependent (Castells, 1999). If bad news is published about a company, an activity branch or a country, it may cause a massive withdrawal of the capital invested, since investors are always seeking higher returns. That is why they are aware of all information that might risk and influence profitability of their investments.

\section{Rumors and the stock market}

Rumor is the transmission of information among people in a variety of ways: orally, electronically, or any other media without verifying its veracity. Knapp (1944, p.22) defines rumor as "[...] a proposition for belief of topical reference disseminated without official verification". According to Peterson and Gist (1951, p.159), 'Rumor', in general usage, refers to an unverified account or explanation of events, circulating from person to person and pertaining to an object, event, or issue of public concern". From these definitions it is possible to observe that rumor is based on the disclosure of unconfirmed information, which is interesting to a target public anyway.

Prasad (1935) affirms that anxiety, importance, ambiguity and belief are important elements for the 
transmission of rumors. This way, a rumor persists because of how important a fact or ambiguous event is for a specific group along with anxiety and uncertainty that lead the group to not verify the veracity of a rumor. Allport and Postman (1947) believe that people are motivated by the importance and ambiguity of a specific fact which lead them to disclose a rumor in search for better answers and explanations.

Due to its credibility in face of the public, when a rumor is broadcasted by any of the media of communication, it spreads faster. If it reaches a large number of believers, the company has to interfere and explain the rumor to the public or, in some cases, deny the information.

Under some circumstances, rumors can reappear. There is the cyclic rumor, which appears when an ambiguous or anguishing event happens repeatedly in the same or similar way as it happened to a specific group in the past. Another reason that makes a rumor reappear is when it was not well explained in the past or there is no consensus about it.

Because of the short span of rumors, a lot of financial rumors can arise, spread and vanish in a single day, but they can last if the official source does not answer it, or does it in an ambiguous way. Furthermore, the stock market has some characteristics that favor the arising of rumors, being the investor's uncertainty one of the most important of them, once their decisions are a bet on the future. In addition to uncertainty, the need for speed in the negotiation leads investors to look for information without enough time to check its origin or accuracy.

There are cases in which investors are interested in disclosing a rumor or even provoking it to obtain some advantage over a price movement. But it is risky, since credibility given to a rumor depends on the attitude of an investor in view of the risk, as some investors know the extent of their losses if a rumor is unfounded (Kapferer, 1993).

Müller (2006, p.113, our translation) ${ }^{3}$ says that many investors try "[...] to obtain information before it becomes official or public, because when it happens, those who obtain it have no advantages anymore". However, those who use insider information to guide their own investments may be punished by the authorities of the market.

The stock exchange and the regulatory agency demand transparency and availability of information to all investors whether on performance, financial situation or any other material fact that can change the future perspective of a publicly traded company. However, despite the control on compliance with information disclosure, including penalties for those who break these laws, "The financial market considers the rumor one of the structural elements that define its behavior and dynamic configuration" (Martins, 2008, p.17, our translation) ${ }^{4}$.

\section{Methods}

As a research strategy, a case study about Petrobras is used. The stock of the company was the most negotiated, PETR4, during the years of 2007 and 2011 in the Stock Exchange of São Paulo (BM\&FBovespa); the sample also includes other nine companies. The choosing of these ten companies was done through the sum of the financial volume of trading of each stock of the companies listed in the stock exchange (Table 1). They were chosen because the trades with their stocks involved a large amount of money. The historical quotations of this period were used, since they can be freely downloaded from the stock exchange website after filling out a specific form.

The table is organized by its financial volume in descending order. Participation in the whole financial volume is calculated by dividing the financial volume of each stock by the total volume in the market between the years of 2007 and 2011 (R\$ 6.3 trillion). Itaú stock symbol changed from ITAU4 to ITUB4 on May 20, 2009 because of the merge of Banks Itaú and Unibanco.

Information regarding the communications of companies over the past five-year period explaining unofficial information about their businesses disclosed by the press was also collected from the website. After reading these documents, it was possible to prepare a

\footnotetext{
3 "[...] obter as informações antes que elas se tornem oficiais ou de domínio público, pois quando isso acontece, não conferem mais nenhuma vantagem para quem as detém".

4 "O mercado financeiro tem no boato um de seus elementos estruturantes, definindo uma nova configuração de seu comportamento e de sua dinâmica".
} 
Table 1. The ten stocks with greatest financial volume (from 2007 to 2011) - based on the historical quotation of BM\&FBovespa.

\begin{tabular}{llcc}
\hline Stock & \multicolumn{1}{c}{ Company } & Volume (R\$ billion) & Participation in total volume (\%) \\
\hline PETR4 & Petrobras & 801.44 & 12.72 \\
VALE5 & Vale & 772.87 & 12.26 \\
ITAU4/ITUB4 & Itaú & 222.59 & 3.53 \\
BBDC4 & Bradesco & 189.10 & 3.00 \\
OGXP3 & OGX Petróleo & 183.79 & 2.92 \\
USIM5 & Usiminas & 157.49 & 2.50 \\
GGBR4 & Gerdau & 143.35 & 2.27 \\
BVMF3 & BM\&FBovespa & 131.25 & 2.08 \\
CSNA3 & Cia. Siderúrgica Nacional & 130.76 & 2.07 \\
BBAS3 & Banco do Brasil & 127.21 & 2.02 \\
\hline Sample & & 2859.86 & 45.38 \\
\hline
\end{tabular}

Source: By authors (2012).

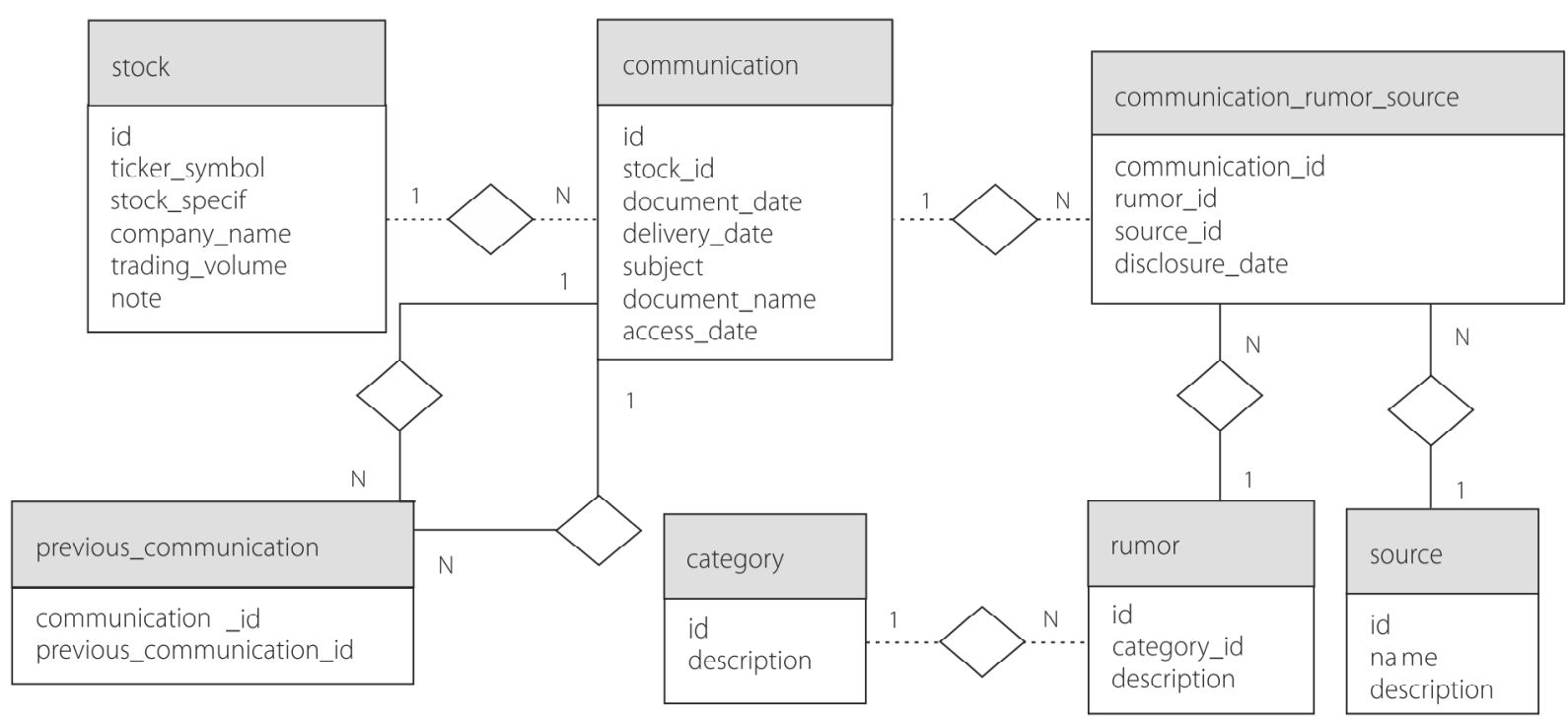

Figure 1. Diagram representing information collected.

Source: By authors (2012).

representation of information about rumors and categorize them by subject.

The diagram above (Figure 1) shows how the information withdrawn from the communications of the companies are related. That diagram was also applied to a database built in an open source SQL (Structured Query Language) database management system to store and recover the information collected from these documents.

A stock may have many communications and a communication may quote other communications

before them or be quoted by others after them. Besides, a communication may be about many rumors or viceversa. It is also noticeable the need to classify the rumors by subject and group them by theme.

Rumors disclosed by the press about Petrobras and the communications presented to clarify those rumors were counted by the date they occurred. Moreover, for each of these dates, some information was extracted from the database, such as the close price of the day, the variation of it in relation to the previous close 
price and the financial volume. It was withdrawn in order to analyze the influence of the rumors on the price of the stocks highlighting those that cause some oscillation of $+/-5 \%$.

\section{Results}

A total of 108 communications from Petrobras were collected. They refer to 117 rumors disclosed by the press during the years between 2007 and 2011. Most of the rumors refer to the production of oil (26\%), and others refer to investments (25\%) and takeovers (14\%). From 117 rumors (Figure 2), three of them reappeared in other dates (recurrent rumors), totalizing 121 appearances.

In 2007,41.66\% of the rumors were related to oil production and speculation about the potential of the Tupifield, and $33.33 \%$ of the rumors were about the takeover of refineries and companies. In 2008, the number of rumors increased 258.00\%. On April 14, 2008, the Reuters Agency published a rumor about the General Director of the Agência Nacional de Petróleo (ANP, National Oil Agency). According to the rumor, the Agent said that in the Carioca field, at Santos basin, they might have reserves of approximately 33 billion barrels of oil. The financial volume on this day was $\mathrm{R} \$ 2.24$ billion, the $5^{\text {th }}$ greatest volume within the whole period studied for this company, and four times more than the day before. On September 8 ,
2008, the stock price closed dow -5,02\% (Figure 3) due to a rumor that the potential of pre-salt reserves from Espirito Santo was not that promising according to some specialists. The day after, Petrobras sent a communication that did not clarify the situation and PETR4 price fell more $-6.31 \%$.

On October 10, 2008, the stock price had a great falling as soon as Petrobras confirmed that was canceling its investments in Ecuador. On the 15 $5^{\text {th }}$, the company denied the rumor about finding a great quantity of oil in Tupi field causing a variation of $-12.09 \%$ in the stock quote. On November 26, 2008, there was a rise in the price of $+5.99 \%$ after Petrobras affirmed that all the allegations that the company was negotiating the acquirement of $30.00 \%$ of an Argentinian refinery were not true. On

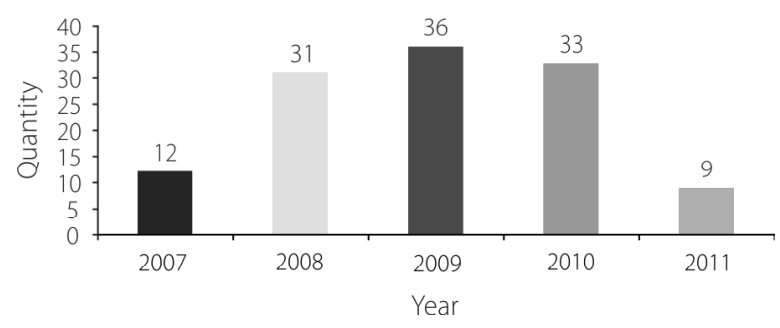

Figure 2. The amount of rumors about Petrobras per year. Source: Based on communications collected from BM\&FBovespa website (2013).

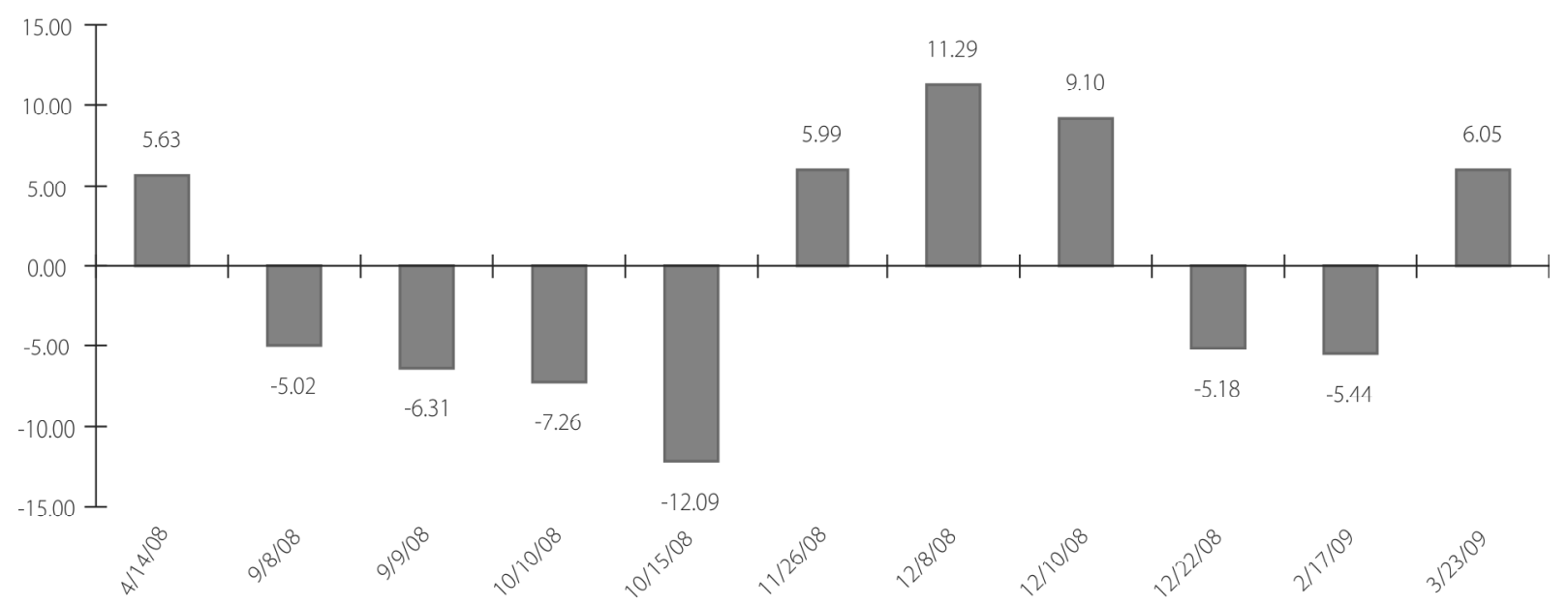

Figure 3. Variation of $+/-5 \%$ at PETR4's quotation due to rumors and clarifications - based on communications and historical stock quotes. Source: By authors (2013). 
December 08, 2008, the prices went up $+11.29 \%$ after responding to rumors that had created doubts about the company's ability to obtain money to finance investments.

On December 10,2008, the prices went up $+9.10 \%$ due to information about the speculations on the business plan of 2009-2011, which had appeared the day before. On December 22, 2008, unofficial information about the business plan reappeared. Prices went down -5.18\% after the company responded that the plan analysis had not been conducted. The above situations show that rumors may cause gains and losses on the stock prices as well as explanations provided by the companies.

The hugest quantity of rumors appeared in 2009. As it had happened the year before, rumors about investments (27.77\%) and oil production (30.55\%) emerged due to speculation about the feasibility of pre-salt wells. On February 17, 2009, the stock prices went down -5.44\% after Petrobras denied that had discovered oil in the Persian Gulf. On March 23, 2009, the stock quote went up $+6.05 \%$ due to unofficial information that the company had adopted a huge plan to reduce expenses.

In 2010, the quantity of rumors was still high. Most of them were about takeovers and investments (42.42\%). There were some other rumors concerning production and the issuance of shares and contracts (45.50\%). As for takeovers, there were two rumors stating that Petrobras was in talks to acquire stake in Galp Energia Company. With regard to production, there were further speculations about the Tupi area and some alleged findings of pre-salt oil. There were also speculations about the capitalization of Petrobras still that year.

The year of 2011 was the period with the smallest quantity of rumors: $44.44 \%$ about investments and a lot of speculation about the business plan for 2011-2015. Two incidences of the same rumor from 2010 about negotiations to acquire stake in Galp Energia must be highlighted. As the rumor persisted, Petrobras was forced to confirm that the transaction could be possible. When the rumor reappeared on February 7, 2011, the company said that the negotiation was unsuccessful, and so speculation was over.

Even though these rumors had been disclosed by the press, the information had not been officially communicated by the companies, but, as Kapferer (1993) and Müller (2006) affirm, when facing uncertainty and the possibility to obtain financial gain or loss if the company confirms the information later, some investors choose to negotiate the shares based on rumors foreseeing the formalization of such information.

Irrespective of focusing on just one company, the above mentioned results prove the influence of rumors on the variation of the stock quote of a great company such as Petrobras. Even though they know the information cannot be trusted, investors keep betting on the credibility of the media of communication. On the other hand, information and explanation provided by the companies help the stock price fluctuations as well.

\section{Final Considerations}

Rumors are transmitted in the stock exchange because they meet an appropriate environment. Once the investment in stocks is a bet on the company's future, rumors may arise to fulfill the lack of knowledge of investors, who are eager for more information for decision making. The data collected and analyzed for this paper cover a part of the rumors that circulate the stock market. They are those disclosed by the press. Media increases the speed of rumors transmission and investors consider it trustable.

In 2008, 2009 and 2010 the amount of rumors about Petrobras was bigger. In 2009, there was a boom and a lot of rumors were related to speculation about pre-salt oil reserves. The rumors that appeared in 2008 were those that had a greater influence on prices. By coincidence, there was a great financial crisis and a lot of uncertainty arose, as well as a bigger risk aversion, in 2008. The pre-salt exploration also began in 2008. It was possible to observe that the explanation given by the companies can interfere in the variation of prices as well.

Within the period chosen, a huge quantity of rumors about oil production and investments of Petrobras appeared. Both are important subjects for the financial health and growth of the company. Rumors that caused the greatest variation on prices were those about oil discovery and speculations about the volume of presalt reserves, particularly in 2008. In addition to the issues 
mentioned, the capitalization process of the company was also a rumor target in 2010, and the press gave great emphasis on it. At present, the other nine companies are

\section{References}

ALLPORT, G.W.; POSTMAN, L. An analysis of rumor. Public Opnion Quaterly, v.10, n.4, p.501-517, 1947.

CASTELLS, M. A sociedade em rede. 6.ed. São Paulo: Paz e Terra, 1999.

KAPFERER, J.N. Boatos: o mais antigo mídia do mundo. Rio de Janeiro: Forense Universitária, 1993.

KNAPP, R. A psychology of rumor. Public Opnion Quaterly, v.8, n.1, p.22-37, 1944.

LE COADIC, Y.F. A ciência da informação. 2.ed. Brasília: Briquet de Lemos, 2004. under analysis, but it is already possible to presuppose that the hugest quantity of rumors within the period selected concerned Petrobras.

MARTINS, V. Oboato como simulacro: uma investigação sobre a comunicação no mercado financeiro. 2008. Tese (Doutorado em Comunicação e Semiótica) - Programa de Estudos Pós- Graduados em Comunicação e Semiótica, Pontifícia Universidade Católica de São Paulo, São Paulo, 2008.

MÜLLER, L.H.A. Mercado exemplar: um estudo antropológico sobre a bolsa de valores. Porto Alegre: Zouk, 2006.

PETERSON, W.A.; GIST, N.P. Rumor and public opnion. American Journal of Sociology, v.57, n.2, p.159-167, 1951.

PRASAD, J. Psychology of rumor: a study relating to the great Indian earthquake of 1934. British Journal of Psychology, v.26, n.1, p.1-15, 1935. 
